\title{
CRACK USERS: LIFE STORIES AND SUBJECTIVITY IN AUDIOVISUAL NARRATIVES
}

\author{
Usuários de Crack: Histórias de vida e subjetividade em narrativas audiovisuais \\ Usuarios de Crack: Historias de vida y subjetividad en narrativas audiovisuales
}

VIRGÍNIA LIMA DOS SANTOS LEVY

DANIELA RIBEIRO SCHNEIDER

\begin{abstract}
Considering crack abuse as a problem of Public Health, this research aimed to understand the relationship between the life stories and the "being projects" of crack users with the consumption of the substance and related problems. 5 participants were asked to do videos about their life stories and to talk about the process of reflection on their trajectories, thinking about aspects addressed or not of their lives in the films produced by them. The data produced were analyzed according to the Content Analysis proposed by Ruiz-Olabuénaga. It was noticed the act of consuming crack as another human act who creates the subject and his biography, though it is problematic when promotes a "suspension" of the other possibilities of life. It was found that the users themselves tend to adopt standardized discourses on drugs and users, even when they contradict his own life experience, while recognizing that there is something particular in his phenomenon of the use and recovery and treatment 's processes. This research indicates that it is necessary to promote users' reflection about the "person" behind the drug, highlighting the universal and individual aspects of their biographies, with the construction of autobiographical audiovisual narratives as a clinically powerful tool.
\end{abstract}

Keywords: Crack; Life Stories; Consumer Behavior; Personal Narratives; Video-Audio Media.

Resumen: Constituyéndose el abuso de crack como grave problema de salud pública, este artículo es parte de disertación que tuvo como objetivo comprender la relación entre las historias de vida y proyectos de ser de los consumidores de crack con el consumo de la sustancia y problemas relacionados. Se pidió a 5 participantes que hiciesen vídeos sobre sus historias de vida y hablasen sobre el proceso de reflexión sobre sus trayectorias y los aspectos de su vida presentes o no en los videos. Los datos obtenidos fueron analizados de acuerdo al análisis de contenido de Ruiz-Olabuénaga. Se observó que consumir crack es como los otros actos humanos que constituyen el sujeto, aunque se vuelve problemático cuando promueve una "suspensión" de otras posibilidades de vida. Se verificó que tienden a adoptar el discurso normalizado sobre drogas y usuarios, incluso en contradicción con sus historias de vida, aunque que reconocían que hay algo singular en el uso y en sus procesos de tratamiento/recuperación. Esta investigación indica la necesidad de estrategias que promuevan la reflexión de los usuarios sobre el "tipo detrás de la droga", destacando los aspectos universales y singulares de sus biografías, con la construcción de narrativas autobiográficas audiovisuales como herramienta clínicamente poderosa.

Palabras clave: Crack; Historias de vida; Comportamiento del consumidor; Narrativas Personales; Medios Audiovisuales.

Resumo: Constituindo-se o uso problemático de crack como grave questão de Saúde Pública, este artigo é parte de dissertação que teve como objetivo compreender a relação entre histórias de vida e projetos de ser dos sujeitos usuários de crack com o consumo da substância e problemas a ele relacionados. Solicitou-se a cinco participantes que fizessem vídeos sobre suas histórias de vida, e que falassem sobre o processo de reflexão sobre suas trajetórias e aspectos de suas vidas presentes ou não nos vídeos. Os dados produzidos foram analisados conforme a Análise de Conteúdo proposta por Ruiz-Olabuénaga. Percebeu-se o ato de consumir crack como mais um dos atos humanos a constituir o sujeito e sua biografia, embora se torne problemático quando promove "suspensão" das outras possibilidades de vida. Verificou-se eles que tenderam a adotar discursos padronizados sobre drogas e usuários, ainda que contradigam suas próprias histórias de vida, embora reconheçam que há algo de particular na sua trajetória de uso e nos processos de tratamento/ recuperação. Esta pesquisa indica a necessidade de estratégias que fomentem a reflexão dos usuários sobre o sujeito por trás da droga, destacando aspectos universais e singulares de suas biografias, tendo na construção de narrativas autobiográficas audiovisuais um instrumento clinicamente potente.

Palavras-chave: Crack; História de vida; Comportamento do consumidor; Narrativas pessoais; Mídia audiovisual. 


\section{Introduction}

Inside and outside of the field of Mental Health, an important discussion today arises related to the issue of the consequences of the consumption of crack and the contexts of use. In a survey of the subject, between 2000 and 2010, there were found many works on general and universal aspects, focusing on harmful changes in the health of users (42.8\% of the studies in the area), but few were produced in order to understand the subjective aspects of crack users and the implications related to these aspects (only 13.4\%), according to Daniele Farina's dissertation (2012).

This is close to what we found in a literature review, using the "crack users" index, without determination of year of publication, in the databases Scielo, Pubmed and BVS. We found 83 articles, which shows the interest of researchers in the subject. However, with "crack and life history" indexes, only nine articles were found, of which five actually dealt with aspects of crack users' lives (of some specific subject or of the process of transformation of such an area into "Crackolândia" for example). Considering the importance of drawing a crack-user profile, as in $22.2 \%$ of the articles found in Farina's survey (2012), it is strategic to seek a "comprehensive and dynamic understanding of the problem" so that interventions can be planned (Brazil, 2005, 2013a), avoiding closed approaches in only one of several aspects of the question, or closed only in the "offer of 'treatments' inspired by models of exclusion / separation of social interaction users "(Brazil, 2005).

In this way, the concept of a clinic that does not go exclusively to the "disease" appears, avoiding to reduce people to the pathological dimension (Campos, 2005). An Expanded Clinic, that can go beyond disease, beyond the morbid, although without disregarding it (clinic that is still clinical); a clinic that is "centered on the subjects, on the real people, on their concrete existence, also considering the disease as part of these existences" (Campos, 2005). Therefore, the clinic that proposes to "Psychosocial Attention" should encompass psychic and psychopathological but also social aspects. This is the clinic associated with the Psychosocial Care Centers (CAPS) in Brazil, although it is not restricted (nor can it be restricted) to them.

It is from this perspective that this article was proposed, the result of a master's thesis. The general objective of this work was to understand the relationship between life histories and projects of being with the use of crack and related problems, aiming to contribute with subsidies for the extended clinic. For that, a survey of the life histories of some users of crack was carried out; describing the relationship of the person with their current sociological (microsocial) and anthropological (macrossocial) context and their implications in the use of crack, when discussing the function of the use of crack in the life of these subjects through audiovisual narratives. The aim was to "give voice" to crack users, through audiovisual narratives.

\section{Method}

For this work, we proposed a qualitative research through the narrative methodology (Ricoeur, 2012), with a phenomenological basis, in which self-reporting was taken as a "(...) privileged locus" (Carvalho, 2003). In that "locus", the meanings of the relation of the subject to the world and to its own history emerge, allowing the comprehensibility of its project and desire to be and its concrete choices, including its relation with drugs, through the production of videos and interviews. Considering that the crack user is, like the other subjects, someone who constitutes his acts, making sense of his actions and choices (after already) done, according to the Sartrian concept of "subject", we understand that the crack users can, in producing reports about themselves, understand and make others understand various aspects of their life history (both the most particular, singular and the most general, "universal" aspects).

The participants selected for this research were users of crack cocaine, inserted in treatment in a Psychosocial Care Center specialized in problems related to the use of alcohol and other drugs ("Centro de Atenção Psicossocial Álcool/Drogas" - CAPS AD) located in Rio de Janeiro (RJ), for at least one year, in psychological conditions to narrate their own histories, according to the reference technicians who support them in the Health Unit. It was also required that they had previously gone through the "Cinema Workshop" of the CAPS, a space for the production of audiovisual material based on reports (on the most diverse subjects) of those involved in each meeting. In this space, conducted by the researcher from July 2010 to March 2014, the aim was to foster expression, confrontation and dealing with experiences from the creation of videos, thinking about the history and ways of life of users in terms of image, sound and other audiovisual effects. This is why we selected these users: they already had experience with the use of audiovisual language as a form of expression, and good relationship with the interviewer (although two participants only knew the face or rumors coming from other professionals and users of the service). Five users participated in all phases of the research, four of whom still attend the unit assiduously, and one who was away but felt the need to return.

We asked for each participants to construct a short film, in which their describe their own relation with the current context and their life history was the theme, elaborating their own script and editing (choosing the scenes and excerpts that would be composed, as well as its order of presentation and the inclusion of other audiovisual elements, such as still images, photographs, sayings and soundtrack, among others) of the movie. This process of video production was carried out in the presence of the researcher, who used this moment as an open interview, with digital recording previously authorized by the research subjects. The participants were oriented on the possibility of selecting parts that would or would not be dis- 
played, as part of the final product of this dissertation. Thus, data were collected through: 1) Videos elaborated by participants on their own life history; 2) Open interviews during the process of editing these videos; 3) Field diary of the researcher, who recorded the daily research, from proposal to conclusion.

These data were analyzed from the Content Analysis, as conceived by Ruiz-Olabuénaga (2012), for whom reading and comprehension of text cover both the written text and audiovisual texts, "so important and basic for understanding our social life "(Ruiz-Olabuénaga, 2012, pp. 193). For the construction of the analysis, three steps were necessary: the election of the Analysis Strategy, since it is necessary to decide the level of depth of meaning that one wants to achieve; the construction of the Field Text, with the gathering of words, phrases, comments, themes present in the material collec- ted; and the construction of the Investigation Text, which consists mainly of the "categorization of the Registration units that composed the Field Text", when the process of "simplifying by reducing the number of registration units to a smaller number of classes or categories". This process can be seen below.

\section{Results}

In addition to the videos produced by the users, this research had as product the survey of data, examined according to the procedure described previously. In the categorization process, the similar elements cited by the participants and / or observed by the researcher were grouped in Thematic Categories, which were later grouped in Thematic Nuclei, according to the table below:

Table 1

Thematic Nuclei and Thematic Categories

\begin{tabular}{|c|c|}
\hline Thematic Nuclei & Thematic Categories \\
\hline \multirow{8}{*}{ 1. Video Mounting Process } & 1.a - Duration time \\
\hline & 1.b - Chosen location \\
\hline & 1.c-Chosen format \\
\hline & 1.d - Elements of video $\mathrm{x}$ elements of oral history \\
\hline & 1.e - Video Tone \\
\hline & 1.f - Soundtrack \\
\hline & 1.g - Discarded elements \\
\hline & 1.h - Security / insecurity to perform the "task" \\
\hline \multirow[t]{4}{*}{ 2. Consumption of Psychoactive Substances } & 2.a - Use of previous crack \\
\hline & $2 . \mathrm{b}$ - Use of current crack \\
\hline & 2.c - Use of other licit substances \\
\hline & 2.d - Use of other illicit substances \\
\hline \multirow[t]{3}{*}{ 3. Treatment and "Recovery" } & 3.a - Previous treatment methods \\
\hline & 3.b - Current treatment methods \\
\hline & 3.c - Conceptions of "recovery" / "improvement" \\
\hline \multirow{5}{*}{ 4. Relations between the Past and Present } & 4.a - Family History \\
\hline & 4.b - Current Family Bonds/Connections \\
\hline & 4.c - Comments on childhood and adolescence \\
\hline & 4.d - Social vulnerability \\
\hline & 4.e - Other personal problems \\
\hline \multirow[t]{2}{*}{ 5. Planning for the Future } & 5.a - Desires for the future \\
\hline & 5.b - Solid projects for the future \\
\hline
\end{tabular}

Source: Authors themselves 
Articulating these categories and thematic nuclei with the scientific production of the area (which we will do in the next topic), it is possible to perceive many similarities between the discourse of the participants and the academic-scientific discourse, especially if we observe the nuclei of 2 to 4 , which bring themes very common in the literature on the subject. However, it is also possible to perceive many disparities - especially if we observe the difference between the discourse that one wanted to expose in the videos and the speech about one's own life story. At times, it was remarkable the discrepancy between personal experiences and the tone of the videos, which accentuated universal negative aspects, sometimes exacerbating them.

\section{Discussion of the Data}

The study group consisted of 5 participants, with ages between 27 - 54 years, 2 cisgenders women and 3 cisgenders men, with different levels of schooling, marital and professional situations. Three of the five participants had been living in the streets for less than three years. All of them went through special institutions to treat alcohol and other drug abuse disorders (clinics and / or therapeutic communities), and one of them spoke at length about a passage through a mental asylum, although others also had associated consumption of drugs to problematic relationships with the Police / Justice. Currently everyone has a referral address. One participant attends college, and another participant is working, while two others are moonlighting, and two of them have affective relationships.

Based on this information, the group of selected participants covers characteristics observed in the national profile of crack users raised by the Oswaldo Cruz Foundation (2013b; 2013c) research. Although it was not an objective research, and therefore did not seek a numerical representation, the profile of the participants of this research was very much in line with the profile found in the Fiocruz Research, except for the average age, which was 42 years in this research - a little older than the profile raised by Fiocruz (30 years), and therefore even further removed from the social imaginary of "young people who engage in drugs and soon die" without a varied repertoire of "feats" in their life histories . As in the profile surveyed by Fiocruz, however, the participants in this research were mostly single, male, with low, but not null, schooling, without being in a street situation, with greater involvement with informal work $(60 \%)$ than with illicit activities (6.4 to 9\%) (Fiocruz, 2013b; 2013c).

As we could see, in telling their life stories, the participants included many elements for which they point out previous research, such as that of Fiocruz. Be it in the choices during the filming process, or in the speeches produced, the participants drew a kind of "profile" of the crack user that does not contradict the "National Profile": women and men who had contact with the schooling process. Only one participant only had such contact later in relation to the Brazilian educational legislation; another attends Higher Education, and it is in college that he initiates his use of drugs. This data points to the need to invest in new models of programs to prevent the misuse of alcohol / other drugs in academic settings.

This need also corroborates the data on the schooling of crack users in "scenes of use" of Fiocruz (2013b; 2013c), which had surprised everyone by revealing that the majority of users (55\%) are of people who studied from 5 to 8 years (from grades 4 to 8 ), and not from people who have never passed through the schooling process. It is possible to affirm, therefore, that although the school space may function as a protective factor against the abusive use of psychoactive substances; this does not mean that access to formal education itself, without better prevention / health promotion strategies, overcomes other factors, such as psychosocial issues and even coexistence with other users in and out of school.

Although participant 3 says that he would not start a drug use today, because he now knows what the use of drugs could bring for him (he did not know before using it), it is not to a lack of drug information, but to a lack of ability to deal with issues of life and to achieve a dialogue with the family that the participant attributed to their use of drugs. This would be, according to him, a way of feeling like someone who "is not afraid of anything", a contrast to an identification of himself as someone who has been "very coward" and who, because he cannot understand that "fear is part of our life", deals with him making use of psychoactive substances to forget him. Such a process, similar to the process that allowed the participant 5 to "forget" the traditional values and the rejection of family members and to launch herself into the world as a single woman, childless, heavy rocker and homosexual, and which allowed the participant 4 to dodge the sense of rejection, injustice and loss that came from being excluded from the sport that he practiced, is close to the concepts brought by Messas (2015) to explain the issue of drug addiction.

For this author, the use of crack provides an intense "horizontal paralysis" (Messas, 2015, p. 130), which begins with the search for attenuation of ambiguities regarding friends and the future that drunkenness offers, a method that becomes bad for the state of isolation and false self-sufficiency that can occur in the consumption of substances such as crack, especially when the social context restricts possibilities. If use is a mechanism that allows "getting out" of itself and its "existential questions", continuous use can exacerbate this "exit" (or, as in the song [Heluy, 1981]) participant 2 always sang in her show, makes them live only by "appearances"1).

1 For a decade, the participant made a weekly music show in which she sang some songs dressed "as a man", and gradually undressing to reveal that she was a woman. Searching the Internet, I found the music that was always the second to be sung in this show: "Appearances" ("Aparências", from Heluy, 1981). In this song, this excerpt appears: "Appearances, nothing more, nothing more, sustained our lives that, although ill lived still has a hope of being able to live." ("Aparências, nada mais, nada mais, sustentaram nossas vidas que, apesar de mal vividas tem ainda uma esperança de poder viver"). 
They restrict in such a way the possibilities that the aspects of the subject's biography are being abandoned, and thus increasingly difficult to resume (and serve as a starting point for new possibilities for the future - a subject that had been so difficult for the participants).

Beyond the report on the consumption (and desire $\mathrm{x}$ abstinence) of psychoactive substances, we saw, in this work, a series of human activities, desires, events, as assimilated by the participants. Using the common language of the treatment models they know, participants reported their life experiences from the perspective of the drug issue ("the restriction of identity to just a paper update", Messas would say [2015, 135]), which was central even when there were several other factors involved in the course of their life stories. Participant 5, as we saw in the Field Diary, sees in her dissatisfaction with her demanding and unpleasant work and a "suffocating" relationship, as well as a life without leisure activities, a sign of her own instability, of someone who is "weak and does wrong things" (Participant 5).

She thus delegitimizes her own discontent, declaring that she must be satisfied that she has become a person who has a job, family, access to consumer goods. That is, that she has socially "reinserted" herself and that she does not use drugs, as if it is a "recipe" for to be satisfied with the person who she "is" (to follow the socially established standard, rather than to follow what makes sense to herself).

Unaware of the complexity of its own phenomenon (the consumption of drugs), it is surprising for her that only withdrawing this element is not enough to make her feel joyful and motivated for living. This occurred even she recognizing other unique (singular) aspects that constitute her, such as her relationship with a sense of rejection that was constructing (or been constructed) from the situations of her life.

If we consider, as Sartre (1987a), that the ways of engaging in the world and subjectivity are mixed, mutually construct, inseparable, it becomes urgent to seek intervention strategies in which users of Mental Health services with disorders related to problematic use of crack (as well as other psychoactive substances) can rethink their life histories in an integral, multifactorial way. As we have seen, the issue of drug consumption is not, for the participants, a phenomenon isolated from the others that have occurred to them throughout their lives. Although they attribute to him a "central role," they do not fail to perceive the other constituent aspects of his life histories (and, consequently, of himself). This is reflected in the difficulty they reported of talking about their stories without talking about crack, and in the fact that, to talk about crack, they had to talk about other facts in their stories:

So I stayed clean for almost two years. Carnival I relapsed. So ... The relapse is not legal, it's not legal. I was not supposed to talk, but I have to talk because I can't ... (laughs). Oh, I can't be different! (Participant 5)
Another fact to be observed in this study is that, although the drug is declared to be the major impediment of the being projects of the subjects that use it, what has been seen is that many other factors (such as the unfair loss of the place on the boat in which it participant 4 would compete) also present themselves as "impediments". At this point, drug emerges, as participant 3 brings, as a way to reduce fear, distress, and as an instrument to deal with impediments, adversities - something we can see in participant's speech 1:

It was the only way I, since I was a child, learned to live, and chose to live. Because, in this world, I did not have a study, I did not have a "fuck", I did not have any opportunity. The first opportunity I had was to gain a pistol and be able to "form" in the "smoke mouth" ${ }^{3}$ ". Look at that "trip"! It's the dream of any little boy of my days. Because? Never studied, never worked...

Recapturing Sartre's speech about Valéry “[...] he is a petit-bourgeois intellectual ... But not every petit-bourgeois intellectual is Valéry" (Sartre, 1987b, 136) - we cannot say that every subject that was in the same life situations that the participants went through would have produced the same outcomes, or that they would have been built as equal subjects. Participants' own speech brings differences in some aspects, such as the relationship with other users of psychoactive substances, which can be considered as beneficial or as evil (we should remember that, since they were selected in the same Health Unit, participants live with each other, as they live with the same others users of the service, most of the week!).

According to this work, therefore, it is important to value the forms of intervention that value the singular aspects of the users, although many common variables exist among them, such as the alignment to the rationality derived from the Moral Model and / or Biomedical Model, assumed in its treatment, such as in the Alcoholics Anonymous and Narcotics Anonymous groups (Schneider, 2010). Participant 4, for example, starts his video by using the standard start-phrase for mutual aid groups: "Good afternoon! My name is X. I'm one more recovering addict. And I'm here to talk a little a bit about my life".

This type of group is based on a generalizing premise: "if you want what we have, you can do what we have done" (Burns and Labonia Filho, 2011), that is, to reach "recovery", the way is to do exactly the same as other "recovered" ones have done. Paradoxically, even affiliated with this philosophy, those who know it, like the research participants, realize that there is something individual about what they call "recovery":

2 The verb "to form", in this context, refers to the act of assuming commitment before another that also commits itself loyally, reciprocally; in this case, commitment with the colleagues of "gang".

3 Place of sale of drugs in underprivileged communities. 
Now, the recovery is individual, because each one has, makes its recovery in the way that you think is better. Because what's good for me suddenly cannot be good for him. In addiction, what's good for him suddenly cannot be good for me, understand? That's why I say: recovery is individual. [...]. It belongs to each one. (Participant 4)

If the subject is constantly creating himself through his existing in the world, in constant dialogue with him, it is not surprising that, in participating in mutual aid groups, the philosophy of this group also becomes part of the constitution of these subjects (denying or affirming it), as a constituent that helps the subject to "be" or as an "unwanted taper", as well as what happens with the use of the drug itself. This was observed in their speeches: for participant 1 , for example, the only way to include himself in a project of future for himself and for "any little boy of his days" of childhood / adolescence (since "without study and work", he explains) was to join the opportunity to engage in drug trafficking, and the use of crack relates to sexual opportunities that he does not describe as possible without drug mediation. This opportunity responds both to economic yearnings and to feelings of belonging / affiliation, something also described by other participants, such as 4 , who reinsert himself in the world first through the hippie identity, and then by the resumption of contact with the family, passing by the feeling of acceptance in the treatment groups, and participant 2 , whose relationship with sister and friends became, very early, mediated by of drug use. These reports also add to what was obtained by Fiocruz's research (2013a; 2013b), in which, in addition to the desire / curiosity to feel the effect of the drug (without there being room to understand the motivation of the interviewees to desire such an effect), a big part of the interviewees put as factors that triggered the use of crack and similar, peer pressure and family problems or emotional losses.

Thus, in line with the model of the Social Determinants of Health (Buss and Pelegrini Filho, 2015), the consumption and abuse of crack was not restricted, in the life history of these participants, to organic issues, but occurred in a tangle of issues at various levels, from the most particular to the most common, microsocial and macrosocial issues. The relation with the drug was described as a mediator in front of the world, a way of taking part in it, by ignoring other aspects of the reality that was presented to them and that, many times, it was hostile to him: something that is sometimes adequate and necessary, although sometimes it may become bad for restricting the repertoire of possibilities of being / being in the world, as pointed out by Messas (2015).

In this sense, we have seen Thematic Nuclei (and Categories) that alluded to several areas of life that are related to an engagement in the world, brought in the "being-without-drugs" / "being-with-drugs" dichotomy. There were moments when drugs were spoken of as enabling more "palatable" fee- lings and others in which losses were reported that: 1) "led" to drug use, and 2) "elapsed" from drug use; but there was a constant differentiation between being someone who has the drug and being someone who has and deserves the rest of the things and possibilities in the world.

\section{Final Considerations}

More than the desire to do something out of the norm, to adopt an antisocial behavior, or more than something unexpected and powerful that controls of the being of the user, the crack consumption, as well as other human activities, is inserted in the life histories of the consumers from a network of situations and relations of which it is possible to apprehend, a posteriori, a sense. In the execution of the autobiographical narrative, the consumption of crack does not appear as a disconnected element, but as another element among many others that reveal "senses of being", although it has a prominent role. This role can be attributed not only to the relevance of this use in the life paths of these participants, but also to the participants' current focus on the use / non-use issue, the fact that they were chosen in a CAPS AD, or to have been selected for a survey on crack users, as they were informed in the initial interview and in the presentation of the Informed Consent Form (TCLE), and even by the influence of the media and the current cultural context that throws light on this substance, demonizing it. Likewise, it also reveals the condition of users of a health service, a CAPS AD, who is subjected to a technical rationality that defines them horizons of self-perception of themselves and its sufferings and problems related to the use of substances.

Through the audiovisual narratives, it was possible to understand the use of crack as an experience that had a great weight for the participants and that relates to the way in which the participants' life histories were gaining meaning when they were narrated. It has been found that users themselves reproduce the hegemonic, demonizing logic of crack use, when substance use issues predominate in their speech and use just a little the opportunity to speak about themselves in terms of their unique trajectory. In view of this, they tend to adopt standardized discourses on drugs and users, seeking to pass moral lessons to the likely viewers of their videos, about how not to follow the "nefarious path they have taken". Even though these discourses contradict their own life experiences and the possibilities the participants have been building mediated by treatment / recovery processes or by the resumption of family, affective, study or work relationships, although they recognize that there is something particular about their phenomenon of use and treatment / recovery processes.

Hence the importance of the method of narrative, through the use of audiovisual as a resource for data collection, which encouraged a look of rupture with the hegemonic, by provoking them to think more about their own stories and how to count 
them. With this, the research participant was able to make more in-depth reflections about himself than he would do if he had been told only to speak directly about his stories or to answer previously elaborated questions. This was more visible in the case of participant 4 , which brought, as a result of producing and thinking about the recordings for the video, a change of perspective and attitude towards the issue of returning to work and to sport. At first, he complained about lost opportunities, without to mention other opportunities; in a new meeting, he told me that they had offered him the opportunity to rejoin a Rowing team for veteran competitions at the same club where he trained when he was a teenager, along with the possibility of employment at the same club (he is an instructor of two modalities of martial arts). He says he was not excited before, but now he was thinking of accepting it. He ask me if I think you should. We talked about how much he resented, in his video, of not being able to return to the sport, and he decides, after hearing me, that it is valid to accept. This way, he does the reverse of the existential bottleneck that the problematic use of crack, together with its other circumstances of life, had helped to produce, and then he can see again as possible the opportunities that were found in the world (many opportunities were denied them because he was a crack user, but others opportunities already showed up and he did not "believe" in them and / or in himself...).

This "bottleneck", which leaves the user "standing on the corner" ${ }^{4}$, as said participant 1 , as we could see, is not restricted to crack, but can happen in many different ways, and ending up being something functional or not for the subject. Because of this, it is important to take a critical look at treatment proposals that focus on the single goal of abstinence and focus on the promotion of identity roles that are based on a single element - pushing drugs away, in a rigid way, such as happens in some specialized clinics and mutual aid groups, disregarding the rich life stories behind this problematic use. With a philosophy that considers all users to be equal, these places can make it difficult to open the individual to the lost possibilities of being and not to focus on the construction of new possibilities in a more personalized way, consistent with their abilities, desires and their history, constituting a new type of existential bottleneck (by switching from a supposed "live-for-crack" to "living-for-the-mutual-help group"), which hampers the process of social reintegration and resumption of activities (work, study ...) and socio-family ties.

From this perspective, it can be said that this research points to the need for intervention strategies in which users of Mental Health services with disorders related to the problematic use of crack (as

$4 \quad$ The participant gives a new meaning to an expression that appeared in the refrain of a song that used to sing in the Unity: "Standing in the Corner" ("Parado na Esquina"). While in this song we have a character who says to stand in the corner to observe the girls who pass towards the funk prom, raising the possibility of to relate to them in the near future, in the participant's speech are "standing in the corner" those who, buried in the nearby cemetery, will no longer have any possibility of performing new acts, because their lives are closed. well as other psychoactive substances) can rethink their life histories in a comprehensive, multifactorial and "personalized" way, where the way in which the user understands and constructs himself and his relationships with the world (i.e., his life history) is respected and taken into account, not just his symptoms common. In this sense, one of the possibilities for intervention is the very use of therapeutic workshops in which we can work with audiovisual narratives, such as those developed in the Service, in order to foster reflection on the possible relations between themselves and the world, as a way to broaden the horizons of the future, and support the plannings based on these new horizons, a process advocated by the National Mental Health Policy, supported by the PTS - Unique Therapeutic Project. Although the PTS brings together the proposal of joint professional-user construction of personalized care, supported by the particularities of each case, such particularities become invisible in the face of attempts to standardize treatments. In this way, the users ends up not asking for themselves, for their sense of being, but for the substance, as we could notice in the surprise of the participant 3 with the proposal of this research.

It is therefore proposed to reflect on the clinical potency of this device, to unfocus on issues simply related to crack abuse, but to uncover the range of human actions that lie behind this "smoke screen". In this way, the creation of workshops in which one can both watch audiovisual narratives and create one's own media can serve as a method for other research and clinical topics, and even for professional training - mainly for the training of professionals who need to leave the generalizing models and learn to work under the logic of "case-by-case", of the link, the bond, of the production of devices that allow the irruption of the subject within the clinic and as a mediation to resume his being project in question in the situation of supposed dependency, especially when it comes to population victim of social stigmas.

\section{References}

Brasil. Ministério da Saúde. (2005) Reforma Psiquiátrica e Política de Saúde Mental no Brasil. Conferência Regional de Reforma dos Serviços de Saúde Mental: 15 anos depois de Caracas. Disponível em: <http:// bvsms.saude.gov.br/bvs/publicacoes/Relatorio15 anos_Caracas.pdf $>$. Acesso em: 11 jun. 2013.

Brasil. Ministério da Saúde (2013a) Secretaria de Atenção à Saúde. Departamento de Atenção Básica. Saúde mental (Cadernos de atenção básica, 34). Brasília, DF. 176 p. Disponível em: <http://189.28.128.100/ dab/docs/portaldab/publicacoes/caderno_34.pdf >. Acesso em: 15 set. 2015. 
Brasil. Ministério da Justiça. Secretaria Nacional de Políticas sobre Drogas/ Fundação Oswaldo Cruz. (2013b) Estimativa do Número de Usuários de Crack e/ou Similares nas Capitais do País - Livreto domiciliar. Rio de Janeiro: FIOCRUZ. Disponível em: < https:// www.antidrogas.com.br/downloads/Livreto_Domiciliar_17set.pdf $>$. Acesso em: 21 jan 2014 .

Brasil. Ministério da Justiça. Secretaria Nacional de Políticas sobre Drogas/ Fundação Oswaldo Cruz. (2013c) Estimativa do Número de Usuários de Crack e/ou Similares nas Capitais do País - Livreto epidemiológico. Rio de Janeiro: FIOCRUZ. Disponível em: < http://fileserver.idpc.net/library/Livreto-epidemiologico-brazil.pdf> . Acesso em: 21 jan 2014.

Burns, J. E.; Labonia Filho W. (2011). Capítulo 3: Grupos de ajuda-mútua no tratamento de pessoas dependentes de substâncias. In: Brasil. Ministério da Justiça. Secretaria Nacional de Políticas sobre Drogas. Encaminhamento de Pessoas Dependentes de Substâncias Psicoativas: Módulo 5: Brasília: SENAD.

Buss, Paulo; Pelegrini Filho, Alberto. (2007). A Saúde e seus Determinantes Sociais. Physis: Revista de Saúde Coletiva (Online), v. 17, n. 1. Disponível em: <http://www.scielo.br/pdf/physis/v17n1/v17n1a06. pdf> . Acesso em: 05 mar. 2015.

Campos, G. W. (2005). Saúde Paidéia. São Paulo: HUCITEC. $2^{\mathrm{a}}$ Edição.

Carvalho, I. M. C. (2003). Biografia, Identidade e Narrativa: Elementos para uma análise hermenêutica. Horizontes Antropológicos (Online). v. 9 n. 19. Disponível em: < http://www.scielo.br/scielo.php?script=sci arttext\&pid $=$ S0104-71832003000100012 $>$. Acesso em: 17 jul 2014.

Farina, D. (2012). Drogas: Uma revisão sistemática da literatura entre 2000-2010. Dissertação de mestrado não-publicada - Universidade Federal de Santa Catarina, Florianópolis.

Heluy, J. Aparências. [Gravado pelo artista Márcio Greyck]. Em 4 sucessos do momento [Compacto]. Rio de Janeiro, CBS. (1981).

Messas, G. (2015). A existência fusional e o abuso de crack. Psicopatologia Fenomenológica Contemporânea. v. 4, n. 1. Disponível em: <http://www.revistapfc. com.br/img/pdf/artigos/124_140_GMessas_final. pdf $>$. Acesso em: 26 set 2015 .

Parado na esquina - MC Roba Cena. Disponível em: <http://letras.mus.br/mc-roba-cena/1907749/> . Acesso em: 30/09/2015

Ricoeur, P. (2012). Tempo e Narrativa. São Paulo: Ed. WMF Martin Afonso.

Ruiz-Olabuénaga, J. I. (2012). Metodología de la Investigación Cualitativa. Bilbao: Deusto, $5^{\mathrm{a}}$. Edição.

Sartre, J. P. (1987a). O Existencialismo é um Humanismo. Coleção Os Pensadores, São Paulo: Nova Cultural,

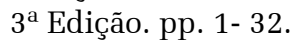

Sartre, J. P. (1987b). Questão de Método. Coleção Os Pensadores, São Paulo: Nova Cultural, $3^{\text {a }}$ Edição. pp. $109-191$.

Schneider, D. R. (2010). Horizonte de racionalidade acerca da dependência de drogas nos serviços de saúde: implicações para o tratamento. Ciênc. saúde coletiva, Rio de Janeiro, v. 15, n. 3, p. 687-698. http:// dx.doi.org/10.1590/S1413-81232010000300011.

Virgínia Lima dos Santos Levy is Psychologist (UERJ) and Doctor Student in Human Sciences at Universidade Federal de Santa Catarina. Master in Mental Health at Universidade Federal de Santa Catarina. Email: virginialevy@gmail.com

Daniela Ribeiro Schneider is Teacher in the Psychology Department at Universidade Federal de Santa Catarina, Psychologist (UFSC), Master in Education (UFSC), Doctor in Psychology (PUC-SP). Email: danischneiderpsi@gmail. com

Received 12.05.2018

First Editorial Decision 21.08.2018

Accepted 28.08.2018 